\title{
АЛЕКСАНДАР КАДИЈЕВИТ
}

\section{БАЛТИЧКА МОДЕРНА У БЕОГРАДУ: ПРОЈЕКТ УПРАВЕ МОНОПОЛА И МИНИСТАРСТВА ФИНАНСИЈА (1908) КРИЧИНСКОГ И ВАСИЉЕВА}

\begin{abstract}
САЖЕТАК:
Синтагмом балтичка модерна у савременој архитектонској историографији се означава специфични регионални огранак међународног ар нуво покрета с центрима у Санкт Петербургу и Хелсинкију, који се од 1900. до 1914. године проширио на Стокхолм, Ригу, Талин и друге балтичке градове. Иако је спајао нордијску и словенску уметничку компоненту, одликовао се стилском уједначеношћу заснованом на чврстим персоналним везама балтичких архитеката. То важи и за знамените руске архитекте Стјепана Кричинског (Степан Самойлович Кричинский) и Николаја Васиљева (Николай Васильевич Васильев), чији је победнички конкурсни нацрт за београдску палату Управе монопола и Министарства финансија (1908) делимично осветљен у српској историографији. Иако истицан, није потпуније сагледан у архитектонском контексту из којег је проистекао.
\end{abstract}

кључне Речи: архийекйура, Србија, Русија, Уйрава монойола, Кричински, Васиљев

ABSTRACT:

The term "Baltic Modernism" in the contemporary architectural historiography is used to denote a specific regional branch of international Art Nouveau movement with the centres in Saint Petersburg and Helsinki, that spread from Stockholm, Riga, Tallinn and other Baltic cities in the period from 1900 to 1914. Although it was a blend of Nordic and Slavic artistic components it was endowed with a stylish consistency grounded on steady personal relationships between the Baltic architects. This also accounts for the renown Russian architects, Stepan Krichinsky (Степан Самойлович Кричинский) and Nikolay Vasilyev (Николай Васильевич Васильев), whose аwarded competition drawing for Belgrade Palace of Monopoly Administration and the Ministry of Finance (1908) has been partially addressed in the Serbian historiography. Albite comprehensive, it has never been fully examined in the architectural context from which it was derived.

KEYwORDS: architecture, Serbia, Russia, Monopoly Administration, Krichinsky, Vasilyev.

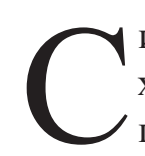

интагмом балиичика модерна у савременој архитектонској историографији се означава специфични регионални огранак међународног ар нуво покрета с центрима у Санкт Петербургу и Хелсинкију, који се од 1900. до 1914. године проширио на Стокхолм, Ригу, Талин и друге градове Балти ка. ${ }^{1}$ Иако је спајао нордијску и словенску уметничку компоненту, одликовао се стилском уједначеношћу заснованом на чврстим персоналним везама балтичких архитеката. ${ }^{2}$ Првенствено су га обележили најнапреднији фински, руски и шведски пројектанти, инспирисани америчким остварењима Хенрија Хобсона Ричардсона (Henry Hobson Richardson), средњовеков- ним и фолклорним наслеђем матичног поднебља. ${ }^{3}$ Стварајући у раздобљу великог привредног и демографског успона балтичких градова, иницирали су корениту реформу еклектичких програма у корист слободнијих просторних решења. Пионир тог правца био је Елијел Саринен (Eliel Saarinen, 1873-1950), ${ }^{4}$ формиран у Финском војводству Руског царства, чије су напредне идеје инстантно прихватили његови санктпетербуршки савременици, изграђујући престоницу од два милиона становника.

Упркос широкој регионалној заступљености, балтичка модерна је суштински представљала периферни нерадикални огранак европског ар нувоа, у којем

65 HACJE 
су интернационалне тековине покрета из Брисела, Беча и Париза прилагођаване локалној традицији и климатским условима. ${ }^{5}$ Отуд су - уместо прозрачних структура од гвожђа и стакла - потенцирани затворени волумени оплаћени гранитом, удубљени портали, уски отвори и коси кровови рашчлањени маштовито стилизованим забатима. У односу на тај доминантни ток, на мањем броју грађевина преовлађују конвенционалне тековине европског ар нувоа, лишене регионалних културних наноса. ${ }^{6}$ Уз то, балтичку модерну не би требало појмовно поистовећивати са архитектонским модернизмом који се у Русији развио након успостављања совјетске власти, док се у западној и средњој Европи појавио уочи Првог светског рата кроз рационалистички огранак ар нувоа, рани функционализам и експресионизам. Пре би је требало сматрати регионалном критичком реакцијом на сувопарни неокласицизам и друге овештале еклектичке идиоме које су балтички народи преузели из великих империја (при чему је руска варијанта изражавала једнаку засићеност).

Поред историографа матичних земаља, тековине балтичке модерне привлаче пажњу ширих истраживачких кругова, јер је део стваралаца тог усмерења радио у различитим светским срединама. То се односи и на руске архитекте Стјепана Кричинског (Степан Самойлович Кричинский) и Николаја Васиљева (Николай Васильевич Васильев), чији је победнички конкурсни нацрт за београдску палату Управе монопола и Министарства финансија (1908) коментарисан у српској историографији. ${ }^{7}$ Иако истицан, није потпуније сагледан у архитектонском контексту из којег jе проистекао. Али да би се то надокнадило, неопходно је концизно представити биографије његових знаменитих твораца.

\section{Стјепан Самојлович Кричински (1874-1923)}

Руски инжењер архитекта Стјепан Самојлович Кричински је рођен у татарској племићкој пољско-литванској породици, која је добила презиме по месту Кричин код реке Березине, где су се Татари населили још средином петнаестог века. ${ }^{8}$ На свет је дошао 20. јануара 1874. на имању у Ошмјанском округу код Виљнуса (тада у саставу Руског царства), као син генерал-мајора Самуила Кричинског и мати Сузане Давидовне. Имао је све предуслове за успешно школовање и стицање хуманистичког образовања. Након што је у родном граду завршио основну школу (1882), а потом и Реално училиште, диплому инжењера архитекте стекао је на Императорском институту цивилних ин- жењера (ИГИ) у Санкт Петербургу 1897. године, уз тамошњу Академију уметности и московско Училиште архитектуре и сликарства, централну установу руске архитектонске едукације.

Приљежан и амбициозан, Кричински се специјализовао за објекте различитих намена и стилова. Уз ангажовање у државним надлештвима, развио је приватну градитељску праксу сарађујући с најперспективнијим руским пројектантима. Од 1899. до 1917. године радио је као главни архитекта Руске пограничне страже у северним, западним и јужним губернијама, градећи повремено и у средњоруским крајевима. Као угледни члан удружења архитеката Санкт Петербурга, поједине пројекте је остварио са Александром фон Гогеном (Александр Иванович фон Гоген, 1856-1914) и Николајем Васиљевом (1875-1958). Паралелно је градио у неоренесансном, неокласицистичком, неовизантијском, неоруском, узбечком и балтичком модерн стилу. Уз пројектовање и грађење, учешће на конкурсима и ангажовање у стручним удружењима, често је путовао по Европи и средњој Азији, обогаћујући стваралачке инспирације. Тако је у Шведској и Финској истраживао школске објекте, у Италији јавне споменике и резиденције, у Француској и Немачкој индустријски фонд, у Туркестану исламске маузолеје. Његов успон правовремено је праћен у руској културној јавности, о чему сведоче коментари у часописима Зоgчий, Сйроииель, Речь, Московский

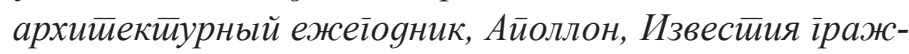
gанских инженеров, Свейильник, Возрожяение России и Мир архийекйуры.

Током плодне пројектантске каријере, Кричински је градио управне и војне зграде, цркве, џамије, приватне једнопородичне куће и стамбене палате за рентирање, позоришта, виле, замкове, електропостројења и здравствене центре. Подигао је 24 објекта у Санкт Петербургу, Новгороду, Либави, Виљнусу, Москви, Самари, Иркутску и Краснодару, од којих поједини више не постоје. Уз то, аутор је више од стотину нереализованих пројеката стамбених, управних и сакралних здања. Међу његовим реализацијама за руске државне установе, цркву, племство и интелектуалну елиту, издвајају се Институт за експерименталну ветерину (1908), Народни дом, Театар Невског округа, дом илустратора Шербова (1910-1911, сл. 1), Храм Св. Николе и Мали дворац у Шуваловском парку Парголова (1915) у Санкт Петербургу и Храм Фјодоровске иконе Дома Романових у Царском селу (са А. Покровским, 1913-1917).

Иако је свој рад подредио архитектонско-урбанистичком успону Русије, као муслиман и потомак 
татарских досељеника, Кричински није запостављао контакте с наручиоцима из вазалних исламских крајева Империје. О томе сведоче његови репрезентативни објекти подигнути у руској престоници: џамија на Кронверском проспекту (с Васиљевом и Гогеном, 1909-1913), ${ }^{9}$ и неопаладијанска резиденција (19131917) последњег бухарског емира Мухамеда Алима Кана (Mohammed Alim Khan), изграђена на Каменостровском проспекту.

Коренита промена друштвеног уређења у Русији, изазвана Октобарском револуцијом 1917. године, знатно је побољшала положај Стјепана Кричинског у хијерархизованој државној администрацији. Грађански рат га затиче у црноморској области Кубан, где је привремено службовао од 1916. године. Прихватајући задатке нове бољшевичке власти, од 1918. до 1920. ради као професор Кубанског политехничког института у Краснодару. По повратку у престоницу 1920. године, прелази у Комесаријат иностраних дела (НКИД). Од 1921. постаје предавач матичног Института грађанских инжењера (предмет Историја архитектуре), а 1922. и начелник градске Архитектонско-грађевинске управе. Након изненадне смрти 9. августа 1923. године, Кричински добија достојан некролог у совјетској стручној периодици. ${ }^{10}$ Сахрањен је у Санкт Петербургу. Један од тројице Стјепанових синова Борис, саставио је списак очевих остварења (1925).

Динамика бурних револуционарних превирања одредила је различиту судбину носилаца санктпетербуршке модерне: Алексеја Бубира (Алексей Фёдорович Бубырь, 1876-1919) погубиле су бољшевичке власти, Николај Васиљев и Федор (Фредрик) Лидвал (Fredrik Lidvall, 1870-1945) стваралачки су стагнирали у принудној емиграцији, док је Кричински уз Иполита Претроа (Ипполи́т Алекса́ндрович Претро́, 1871-1937), видно напредовао у совјетској архитектонској хијерархији.

\section{Николај Васиљевич Васиљев (1875-1958)}

Стјепанов блиски колега са студија Николај Васиљевич Васиљев (рођен 26. новембра 1875. у селу Погорелки, Јарославска губернија), ${ }^{11}$ у школовању је отишао корак даље јер је након Института цивилних инжењера (1902) завршио и санктпетербуршку Академију уметности (1904), код ментора Леонтија Бенуе (Леóнтий Никола́евич Бенуа, 1856-1928). Како је напоменуто, уз харизматичног Лидвала, Васиљев је квалитетом и бројем остварења обележио епоху санктпетербуршке балтичке модерне, подстакнут стваралаштвом Елијела Саринена. Поред Кричинског, плодно је сарађивао

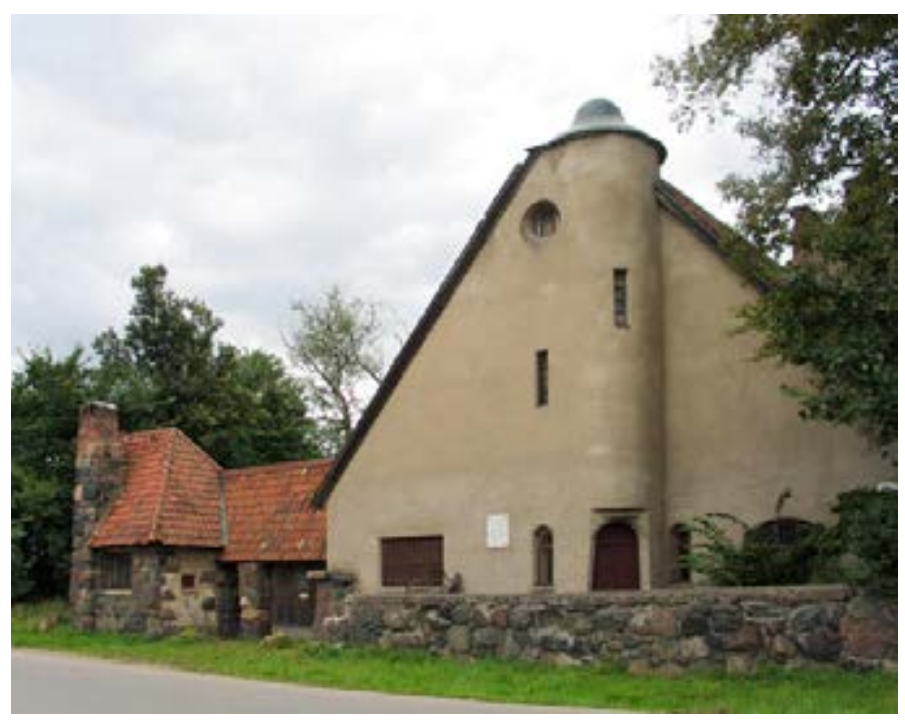

Сл. 1 / С. Кричински, Дом илустирайора Шербова, Санкии Пейербурі (1910-1911). Извор: Музей-усаяьба П. Е. Щербова

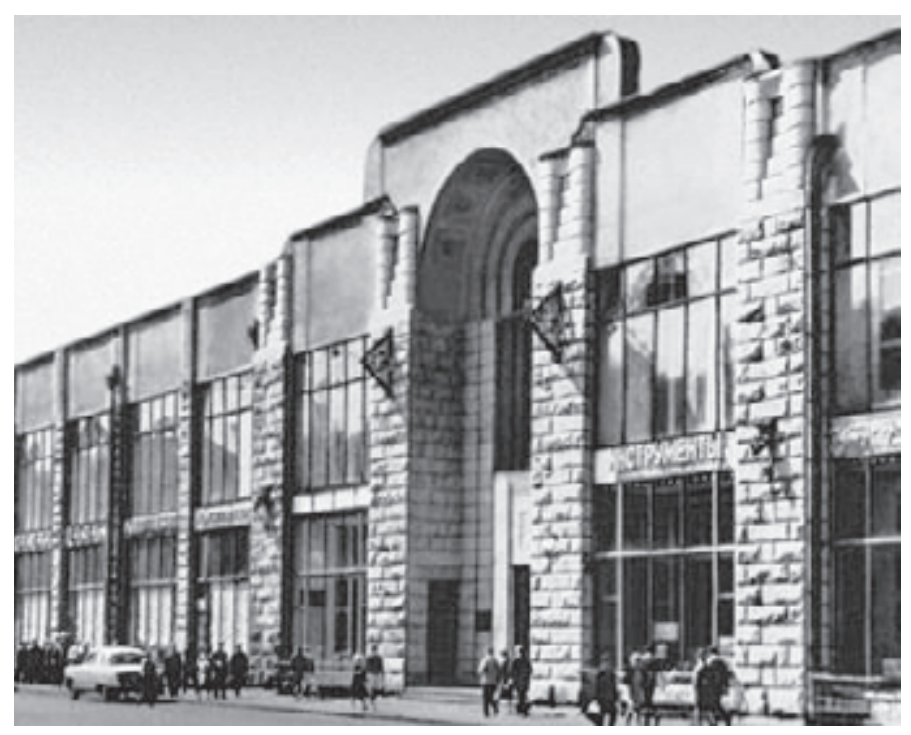

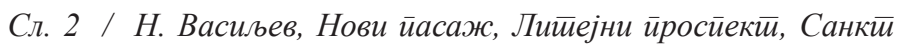
Пеиербурі (1912-1913). Извор: http://www.citywalls.ru [15.2. 2017]

са Бубиром и Фон Гогеном. Примарно везан за Санкт Петербург, градио је и у другим руским и балтичким градовима. У његова најзначајнија дела спадају - Кућа Савицког у Пушкину (1906), уграђена шестоспратница у улици Стремјанаја 11 (1908, са Бубиром) и Нови пасаж на Литејном проспекту (1912-1913, сл. 2) у Санкт Петербургу, Немачко позориште (сл. 3) и Вила Лутер у Талину (са Бубиром, 1908-1910), Градска комерцијална банка са гостионицом „Асторија“ у Харкову (са А. Ржепишевским, 1910-1913) и др. Након двогодишњег боравка на Криму (1918-1920), одлази у принудни турски егзил средином новембра 1920. године. 


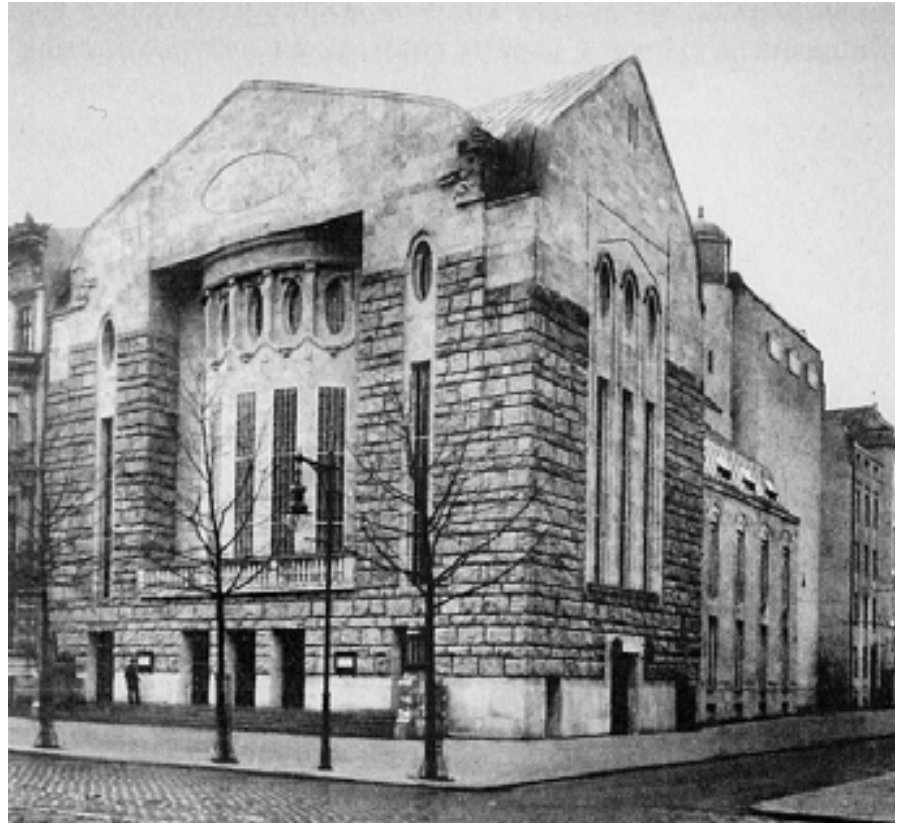

Сл. 3 / Н. Васиьев, А. Бубир, Немачко иоозоришиее, Талин (1908-1910). Извор: http://www.wikiwand.com/ru/Васильев, Николай_Васильевич [16. 2. 2017]

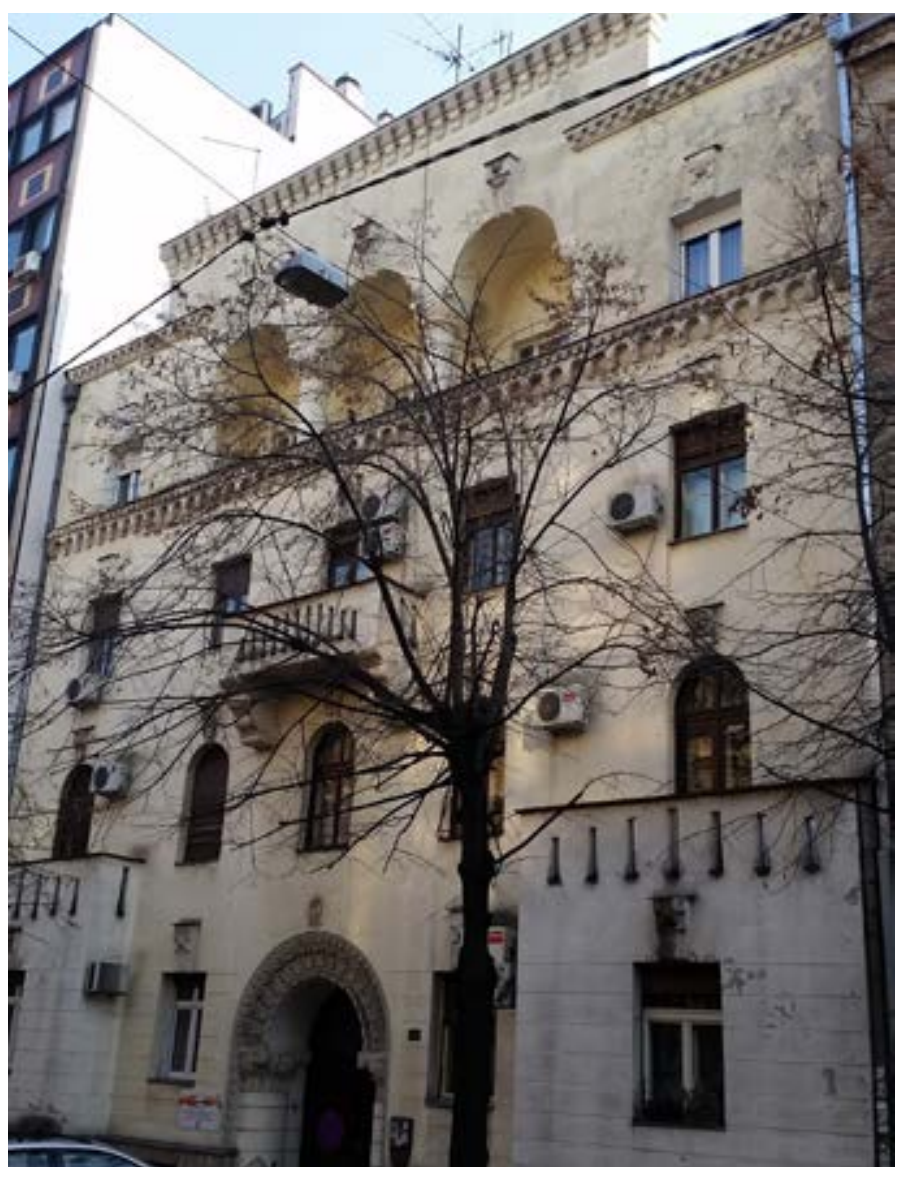

Сл. 4 / Н. Васиљев, Палайа Саве Миленковића, Ул. Светозара Марковића 65, Беоїраg, 1921-1922. (фойоїрафија А. Каgијевић, 2017)
Када су успешно окончани преговори између команданта антибољшевичких снага генерала Петра Врангела (Петиар Николајевич Враніел) и краља Александра Карађорђевића, архитекта Васиљев је у мају 1921. из Истанбула, где је привремено радио, преко Бугарске доспео у Краљевину СХC. ${ }^{12}$ Активно се укључио у београдске архитектонске токове, покренувши са грађевинским инжењером Хрисанфом Виноградовом (Хрисанф Виноградов) пројектантски биро у Косовској улици $53 .^{13}$ Паралелно је сарађивао с Министарством војске (о чему за сада нема довољно сакупљених података). С новом супругом Регином живео је у Авалској 4. Уз пројектовање, у Београду се бавио и позоришном сценографијом и сликарством, излажући поред архитектонских и сликарска дела. ${ }^{14}$ Изузетно поштован у круговима руске уметничке емиграције, приступио је новооснованом Друштву руских архитеката у Краљевини СХС (1922). ${ }^{15}$

Пажњу стручне јавности Васиљев је привукао конкурсним пројектом монументалне палате Министарства шума и рудника, пољопривреде и вода (1921), пријављеним под шифром Бела їлава на црном йољу. Представљен у загребачком Техничком лисииу 1926. године, ${ }^{16}$ његов предлог није имао обележја балтичке модерне већ сувопарног империјалног неокласицизма. Уз два друга рада, Васиљев га је изложио на београдској изложби Сверуског земског савеза априла 1922. године. ${ }^{17}$ Јула исте године, на конкурсу за загребачку Градску штедионицу на Јелачићевом тргу, освојио је престижну другу награду испред педесетак конкурената. Пошто прва награда није додељена, Васиљев се може сматрати најуспешнијим учесником натечаја. ${ }^{18}$ Међутим, како то често бива, у фебруару 1923, дефинитивна израда нацрта и надзор над градњом нису поверени најбоље рангираном такмацу, већ искусном локалном архитекти Игњату Фишеру (Ignjat Fischer, 1870-1948).

Након што је у рустичном неодорском стилу осмислио романтични споменик Незнаном јунаку на Авали (неизведени конкурсни нацрт из августа 1922), ${ }^{19}$ Васиљев се посветио пројектовању интерполираних зграда. Свестран и предузимљив, постао је први лауреат престижне награде за најлепшу престоничку фасаду за период 1920-1923, коју је Друштво инжењера и техничара 1924. доделило интерполираној троспратници Саве Миленковића у Улици Светозара Марковића 65 (1921-1922), ${ }^{20}$ с неосредњовековним балииччким прочељем умереног динамизма. (сл. 4) Симетрично здање богате профилације с лучно уоквиреним лођама, у очима жирија је потиснуло ефектнију, али стилски полиморфну и композиционо мање конзистентну Брашованову Есконтну банку у Нушићевој 4, наметљивије 
усађену у окружење. ${ }^{21}$ Иницирана још 1920. у сарадњи са проф. Душаном Томићем, прва награда је додељена тек јануара 1924. године. Уз чланове УЈИА, једино су руски архитекти емигранти имали право да се кандидују с поднетим нацртима и фотографијама. Васиљев је изградио и задужбинску палату Димитрија Милојевића (Дом ратних сирочади, са инж. Јакобом Козинским, 1922-1924) у Улици Џорџа Вашингтона 12, рашчлањену колосалним коринтским пиластрима и атичким спратом у маниру академизованог класицизма. ${ }^{22}$

Војна управа, надлежна за Београдску тврђаву, почетком двадесетих година се заложила за изградњу репрезентативног трга с палатама четири културно-научне установе, од којих је изведена само зграда Војногеографског института у западном бастиону (1924$1926,{ }^{23}$ претворена у Војни музеј 1956. године). (сл. 5) Она представља пример романтичарског монументализма, контекстуално прилагођеног конфигурацији истакнутог бастиона. ${ }^{24}$ Првобитне пројекте тог вишетрактног здања, Васиљев је такође излагао 1922. године на Сверуској уметничкој изложби.

Сликовите неусиљене силуете, Институт евоцира архитектуру балтичких замкова, тврђава и затвора с краја деветнаестог и почетка двадесетог века. Асиметрија разуђеног корпуса којим доминирају пирамидалне куле, појачава његово уклапање у фортификациони амбијент. Неоромански богенфриз испод завршног венца, као и облици отвора, недвосмислено потврђују балииичко порекло Васиљевљеве концепције, делимично прилагођене београдском поднебљу. Здепасти прислоњени стубићи, усађени у подножје лучне нише прочелног портала, такође представљају карактеристичан моgерн мотив. Романтичарски торњеви, који израстају из масивне структуре, у панорами Београда остварују снажан силуетни ефекат.

На изложби Сверуског земског савеза Васиљев је изложио и пројекат стамбено-пословне зграде трговца Ристе Параноса, изграђене на углу Карађорђеве 67 и Загребачке улице (1922-1923), у конвенционалном маниру санктпетербуршке модерне, са осмостраном угаоном кулом као једином реминисценцијом на средњовековље. ${ }^{25}$ (сл. 6) Угаона четвороспратница богате другостепене пластике и умереног силуетног дејства, садржи приземље и високи мезанин (предвиђен за пословне намене), док су на осталим етажама уређени станови за рентирање. Њен одмерен балтички вертикализам, базиран на ритму пластичких потцелина груписаних дуж оба улична тракта, плени лакоћом и приступачношћу израза. Мотив двоетажног еркера надвишеног залученом нишом, фланкиран стилизова-

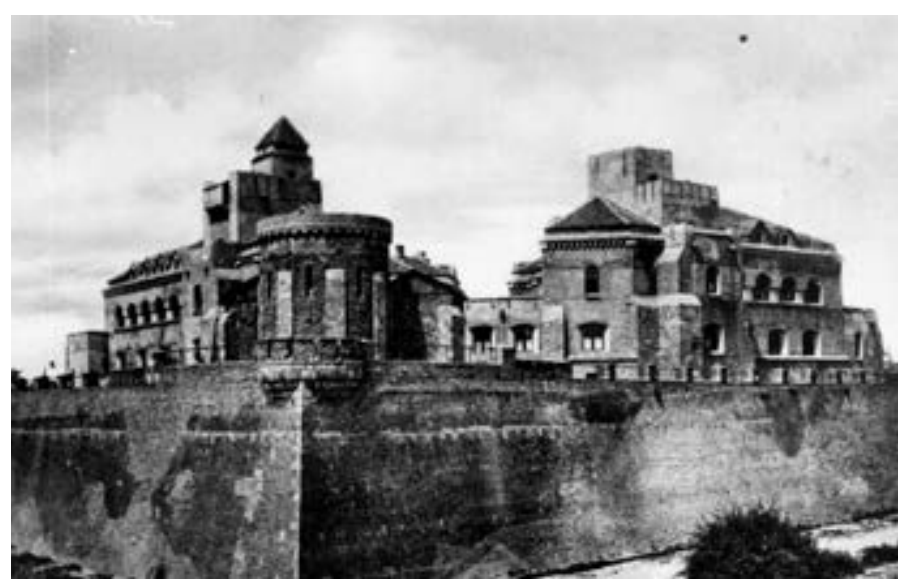

Сл. 5 / Н. Васиљев, Војноіеоірафски инстиийуй у зайаяном бастииону Беоіраяске ииврђаве (1924-1926), разїлеgница

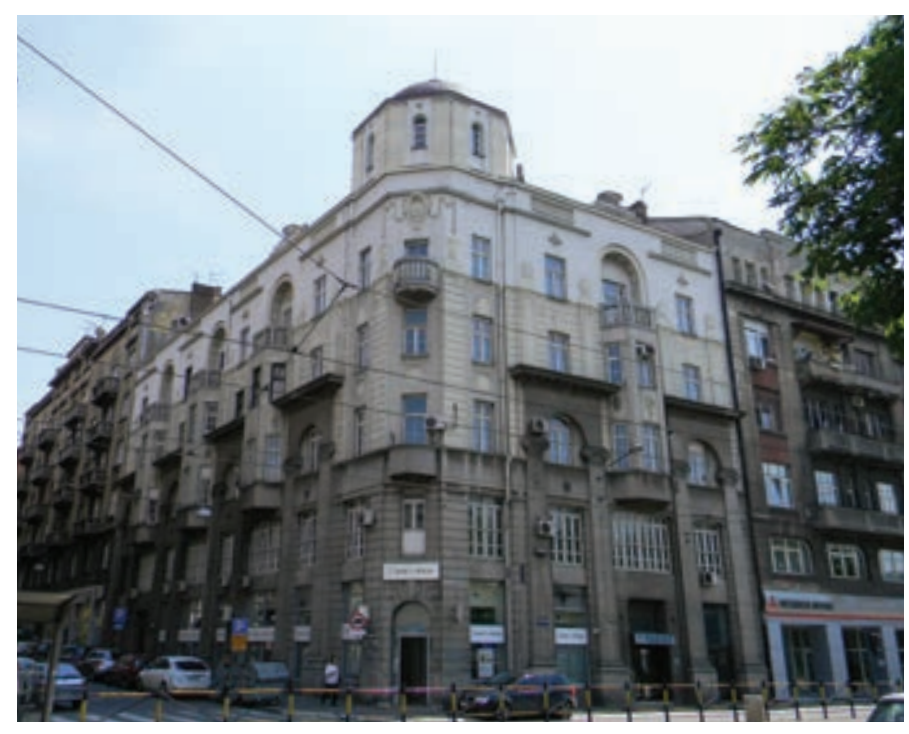

Сл. 6 / Н. Васиљев, Х. Виноіраgов, Палайа Рисие Параноса, Ул. Карађорђева 67, Беоїраg, 1922-1923 (фот̄оірафија А. Каgијевић, 2012)

ним тријумфалним луцима, протеже се дуж обе фасаде као најизразитији композициони елемент (у Загребачкој улици три пута, у Карађорђевој једанпут). Засведена лођа са балустрадом на врху еркера представља карактеристичан руски архитектонски мотив. Узан угаони сегмент фасаде с неупадљивим улазом и два балкона, завршен је сферним кубетом на осмоугаоном тамбуру. ${ }^{26}$ Према Васиљевљевим пројектима извршено је дозиђивање и надзиђивање стамбене зграде Злате Драгутиновић у Солунској 24 (1924). ${ }^{27}$

Коментаришући рад руских градитеља у Београду, архитекта Милутин Борисављевић је 1928. критиковао Васиљевљева дела, пре свега зграду Саве Миленковића, која га је асоцирала на среgњовековну йврђаву 
и онај їалимайијас у Новом їраgу (Војногеографски институт). ${ }^{28}$ Било је и стручњака који су о Васиљеву имали веома афирмативно мишљење. Његов одлазак из Србије, угледни хроничар ликовних збивања вајар Сретен Стојановић 1928. је пропратио речима: Веома йаленимовани архииеккйа Васиљев найусиио је нашу земљу и ойишао у Америку, јер за њеїа није било йосла, gок су мноіи яруіи, са мноіо мањим сйособностима йо-

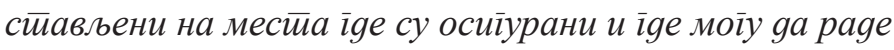
и уиичиу на архииекейуру. ${ }^{29}$

Незадовољан ниским примањима у ратом исцрпљеној Србији, упркос континуитету рада, Васиљев се одлучио за одлазак у Северну Америку, мање оптерећену поратним економским проблемима. Отуд у фебруару 1923. преко Француске одлази у Њујорк. Тај судбоносни прелазак, мотивисан жељом за егзистенцијалном сигурношћу колико и амбицијом да гради монументална здања као некад на Балтику, може се разумети са стваралачког становишта, јер су већину његових београдских остварења представљале ограничене интерполације. Уз то, Васиљев је заслуживао знатно виши статус у југословенској архитектонској администрацији, у којој су предњачили градитељи конзервативнијих схватања и скромнијих међународних референци.

Индикативно је да се Васиљев у САД упутио истим бродом са утицајним балтичким колегом Елијелом Сариненом, подстакнут успехом на конкурсу за облакодер Чикаїо Трибјун (1922), на којем је Финац освојио другу награду, а Васиљев похвалу. ${ }^{30}$ Но за разлику од Саринена, који ће у САД професионално бити знатно успешнији, Васиљев није успео да се наметне америчким наручиоцима, претежно радећи као помоћни архитекта великих пројектантских предузећа, прво „Ворена и Витмора“" (Warren\&Wetmore, 1923-1931), а затим „Шрива, Лемба и Хермона“ (Shreve, Lamb \& Harmon). Касније је радио у комуналним службама (NYC Tunnel and Bridge Authority) и Урбанистичком заводу Њујорка (NYC Planning Commission).

Занимљиво је да Васиљев ни у Њујорку није прекидао сарадњу са Београдом, шаљући писма, нацрте и фотографије. Активно је пратио стручна дешавања са амбицијом да се у њих са дистанце укључи, доставивши већ јуна 1923. документацију на конкурс за најлепшу престоничку фасаду. На позив председника Клуба архитеката београдске секције УЈИА проф. Петра Бајаловића, на Светској изложби у Паризу (1925) изложио је пројекат Палате Министарства шума и руда, пољопривреде и вода, поред 134 експоната истакнутих југословенских колега. ${ }^{31}$ У стилу балтичке модерне са елементима српске средњовековне тради- ције, априла 1927. је послао једанаест скица и статички прорачун задужбинске цркве Милице Нешић у Војвођанској улици. ${ }^{32}$ Степенасто моделована и прекривена различитим врстама камена, тремом спојена с високим звоником, та необична богомоља показује препознатљив рукопис Николаја Васиљева. Али због немогућности да се изведе на преуском плацу, њен пројекат је одбила грађевинска инспекција у септембру исте године. Пред крај међуратног периода, Васиљев је послао и модернистички осмишљен пројекат за Београдску оперу (1940), припремљен са њујоршким колегом пољског порекла Џошуом Левенфишом (Joshue D. Lowenfish), награђен петом наградом. ${ }^{33}$

Не посустајући у индивидуалној имагинацији, Васиљев је из САД учествовао и на другим међународним конкурсима (укључујући и оне у СССР-у), добијајући повремено награде, ретко и реализације (монументални Воскресењски саборни храм у Берлину из 1928 1929). ${ }^{34}$ Пензионисан је 1953. године. Животну сцену напустио је 15. октобра 1958. године у месту Бејсајд на Лонг Ајленду (Bayside, Queens, Long Island).

\section{Балтичка модерна у функцији српског уједи- њења: конкурсни пројекат Управе монопола и Министарства финансија Краљевине Србије (1908)}

Како је напоменуто, сарадњу с Краљевином Србијом, Кричински и Васиљев су отпочели тријумфом на конкурсу за палату Управе државних монопола и Министарства финансија 1908. године. На том престижном натечају, који је организовало Министарство финансија, приложили су нацрт под индикативном шифром Ујеgињена Србија.

Почетком двадесетог века, финансијске установе Краљевине Србије су осетно ојачале, наручујући путем јавних конкурса или директним ангажовањем истакнутих градитеља неопходне просторне капацитете (Управу фондова, Управу монопола и Министарство финансија, Београдску задругу, Врачарску задругу, Врачарску штедионицу, Прометну и Извозну банку). ${ }^{35}$ У време када је у Београду мањкало јавних грађевина, ${ }^{36}$ палата Управе монопола је замишљена као репрезентативна доминанта административног центра на раскрсници улица Кнеза Милоша и Немањине, позиционирана наспрам Министарства војске изграђеног 1895. године (арх. Јован Илкић). ${ }^{37}$ У објави њеног конкурса, учесницима је допуштена стилска слобода, уз моїућности иримене срйских мотиива. ${ }^{38}$

Често наступајући заједно, санктпетербуршки аутори су и на београдском конкурсу освојили престижну 
новчану награду у износу од седам хиљада тадашњих динара. Њихов надахнути пројекат, (сл. 7) прикладнији за оштру северњачку климу Балтика него балканско континентално поднебље, упркос похвали није реализован због криза и ратова који су потресали Србију (1908-1918). Отуд је ова монументална палата саграђена у периоду урбанистичке консолидације Београда (1926-1928), ${ }^{39}$ према новом пројекту руског академика Николаја Краснова (Никола́й Петро́вич Красно́в, 18641938). У њој се данас налази Влада Србије.

Од једанаест приспелих радова, пројекат Кричинског и Васиљева је одабран као најкомплетнији и најприкладнији прописаном програму. ${ }^{40}$ Напоменуто је да је својом умейничком обраяом оямакао ииолико

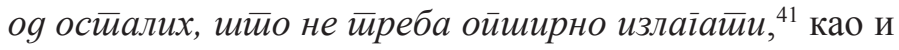
gа су руски уметинищи йоказали gа се може у великим

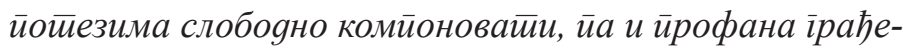

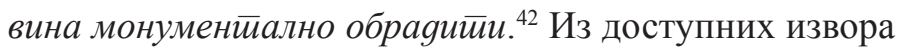
није могуће утврдити појединачни удео надахнутих аутора, поготову што су обојица важила за експерте у обликовању фасада, али се уплив оријенталистичких детаља пре може приписати Кричинском него Васиљеву (због познатих источњачких предилекција). У сваком случају, да је реализован, то би по квадратури био један од њихових највећих објеката.

На конкурсу су могли учествовати само ствараоци словенског порекла из Краљевине Србије и иностранства, због чега је седмочлани жири био састављен од страних и домаћих представника. ${ }^{43}$ Уз угледног академика Владимира Покровског (1871-1931), професора

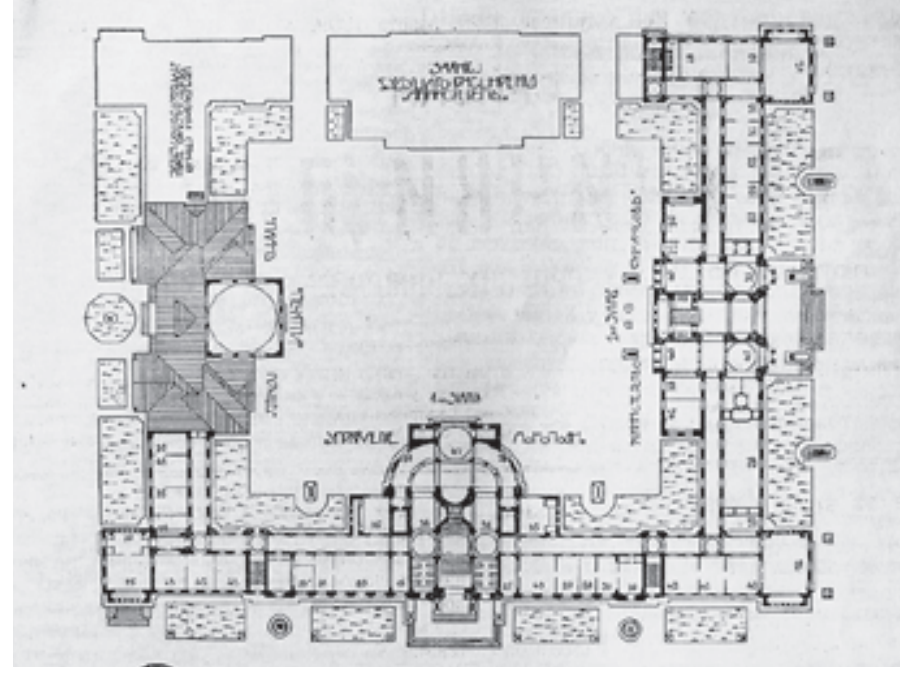

Сл. 7 / С. Кричински, Н. Васиљев, конкурсни ирооекай Уйраве монойола и Министарсивва финансија Кравевине Србије (1908), основа йриземьа. Извор: Срйски иехнички листи 13

(Беоїpag): 29. 3. 1909: 98.

Академије уметности из Санкт Петербурга, и Освалда Поливку (Osvald Polívka, 1859 - 1931), пионира прашке архитектонске сецесије, у жирију су били проф. Андра Стевановић (1859-1929), ректор Београдског универзитета, и локални архитекти Душан Живановић (18531937) и Драгутин Маслаћ (1875-1937), представници Министарства грађевина.

Српска историографија је до сада идентификовала пет од једанаест учесника: руски тандем Васиљев и Кричински, чешког архитекту Франтишека Блаже-

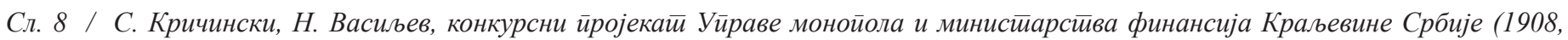

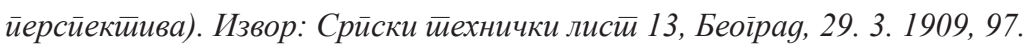

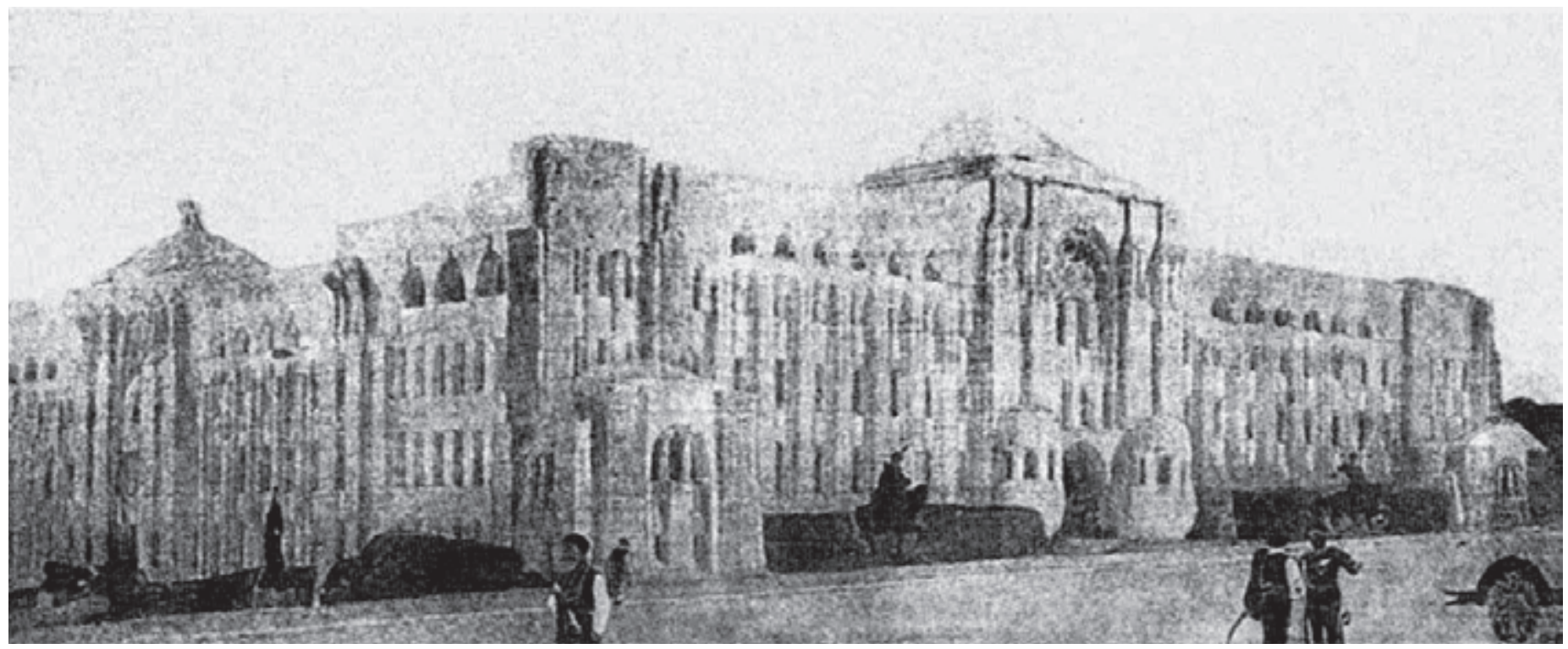


ка (František Blažek, 1863-1944), коме је помагао проф. Хоржица (Нoržica), домаћи дует Никола Несторовић и Драгутин Ђорђевић, док су самосталне нацрте приложили Владимир Поповић и Момир Коруновић. ${ }^{44}$ Наклоњен пројекту амбициозних сународника, Покровски је предложио да им се додели неокрњена йрва найраgа од седам хиљада динара, уместо накнадно одређених пет, као и да им се гарантује извршење овоі озбиљноі

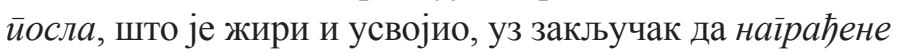
скиие мойу иоослужитии за израяу gефиниииивной йлана. ${ }^{45}$

Планирано је вишетрактно обухватно здање приближно четвороугаоне основе са два доминантна прочелна подужна блока, одвојена унутрашњим двориштем и одељена на трговачко и административно надлештво. (сл. 8) Пошто је веома мало простора било предвиђено за репрезентацију (свечане сале, фоајеи, холови, предворја), предност су добили радни кабинети, дугачки ходници, радионице, продавнице, магацини и лабораторије. Оцењивачки суд је већ на почетку елиминисао пет приспелих нацрта због нейоййностии (међу њима и Коруновићев). Уочене непрецизности су несумњиво проистекле из претерано сложеног конкурсног програма, у којем је требало премостити и разлику у нагибу од осам метара између бочног крила у Улици Адмирала Гепрата и угаоних партија на раскрсници Немањине и Кнеза Милоша, као и прекратког рока за припрему радова што је многе архитекте одбило од учешћа. На мали број пријава утицала је и напета политичка ситуација у Србији и њеном окружењу након аустроугарске анексије БиХ 1908. год., која је по мишљењу хроничара додатно усложњавала разраду захтевног програма, уносећи осећање несигурности. ${ }^{46}$

У образложењу одлуке, жири је оценио да су руски уметници с невероватином лакоћом усиели јасно и ояређено ирредстиавитии своју замисао у ириеежу. Уgаљени оg нас су мойли битии слобоgни оg локалних уских веза и обзира, разрађујући цео огромни плац уместо да фаворизују угаони акценат. ${ }^{47}$ Тиме је зграда у основи постављена развучено, с различито обликованим потцелинама и канцеларијом директора у дворишном тракту, што је делимично отежало комуникацију између њених одељења, али је и непосредно усмерило ка железничкој станици. Са друге стране, развученост плана је требало да омогући потпуније директно осветљавање унутрашњих просторија. Примећено је да маркарница и просторије Управе монопо-

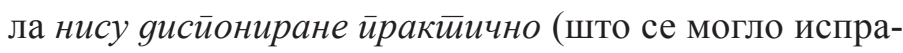
вити дорадом плана), као и да садржај сутерена није документован цртежима.
Истакнуто је да су аутори у спољној обради погодним груписањем маса и диспозицијом главних улаза постигли утисак тражене монументалности, одређене gа йослужи вековима и достиојно ирреgстиави моћ и величину устианове..$^{48}$ За фасаду је речено да је извеgена йоййуно самостиално и уметинички у моgерном стиилу. ${ }^{49}$ Камен као доминантни фасадни материјал, обложен у великим блоковима, астатичној целини је утиснуо потребну монолитност, обуздавајући динамизам ритмичних лезена и средишњих ризалита завршених оријенталистичким куполама (пирамидалне и кришкасте са зашиљеним лантернама).

Устаљени централизам класичне вертикалне субординације, одељене на средишњи блок и периферна крила, свесно је разводњен стапањем зона и контрастима узбуркане пластике (ризалита, лезена, крила, купола, павиљона и скулптура у супструкцији), при чему кохерентност целине није нарушена. Отуд је с правом напоменуто да је упркос нагнутом терену лако, без велике муке, изашла из ьихових руку склаgна комйозииија, йредстиављена у неколико сийурних йотиеза. ${ }^{50}$ Ипак, замерено им је одсуство пожељних српских мотива, уз признање да су успешно испунили захтев за слобояни стилл грађевине, јер њиховом пројекту није недостајало уметничке слободе.

Победнички конкурсни цртеж за перспективни изглед овог здања, начињен на бојеном картону, није могао да се јасније репродукује у стручној штампи, што се види и на фотографији објављеној у Срйском

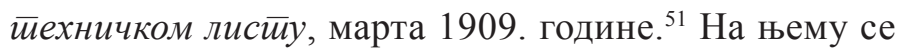
уочавају конвенционалне коњаничке и фигуралне алегоријске скулптуре постављене испред везивних фасадних поља, које нису биле предмет критичких коментара. Архитекти су приложили и алтернативну непубликовану скицу за обраду куле с једним торњем, на углу Кнез Милошеве улице и Немањине, на којој је прекид у спратовима решен компактније.

Хроничар овог престижног интернационалног конкурса, члан жирија арх. Драгутин Маслаћ, ${ }^{52}$ о исходу је у одломцима публиковао исцрпне коментаре, ${ }^{53}$ након што су нацрти излагани на веома посећеној изложби у сали основне школе код Саборне цркве. Учесницима је упутио утемељене примедбе са функционалног и естетичког становишта, остављајући незаобилазан траг за разумевање тадашњих стручних критеријума.

На несвакидашњем здању балииччки узбуркане силуете, употпуњеном средњовековним реминисценцијама и оријенталистичким детаљима, ауторско надахнуће Кричинског и Васиљева је дошло до пуног изражаја, подупирући став Министарства да се при- 
жељкивано национално уједињење може постићи само помоћу јаких финансијских институција. Уникатна и нетипична за тадашњи београдски миље, примарно инспирисана средњоевропским академским узорима, четвороетажна моgерн палата, на којој се зоне органски прожимају уместо хијерархијски разграничавају, по компактности би надмашила потоње Красновљево здање, изведено у крутом неоманиристичком стилу с пренаглашеним угаоним сегментом.

Упркос квантитативној доминацији вертикалних потцелина, пластички динамизам замишљеног здања из 1908. године ритмички се развија у ширину уместо висину. Са функционално-визуелног становишта, осим традиционалистичког фасадног репертоара и одсуства структуралне транспарентности (конструкција и унутрашња просторна подела се не одражавају дословно на спољном омотачу, што је приметио и један члан жирија), ${ }^{54}$ Кричинском и Васиљеву би се могла замерити пластичка разводњеност угаоних партија које смањују прегледност подужних трактова. Ипак, кључни естетички проблем ове архитектонске целине (као, уосталом, и већине остварења Кричинског и Васиљева), лежи у уочљивом контрасту између њених носталгичних морфолошких слојева (садржаних у материјализацији, општој композиционој подели, фенестрацији и пореклу примењених мотива) и иновативног начина моделовања примарних маса (резултирало силуетном астатичношћу подужних волумена, одбацивањем строге водоравне поделе на појасеве, равноправношћу композиционих јединица и подређивањем детаља целини). За разлику од већине савременика којима је транзитивни стилски дуализам стварао неразрешиве методолошке проблеме, руски неимари су јаз између устаљених формалних ограничења и напредних уметничких хтења учинили визуелно подношљивим, не запостављајући функционалну страну програмских садржаја.

У односу на комуникацијски привлачнији хотел „Москву“ (1907, арх. Јован Илкић са санктпетербуршким сарадницима), испуњен вертикалним акцентима, чија плошна декоративност почива на синтези балтичких и средњоевропских искустава, ${ }^{55}$ силуетна изражајност Управе монопола се заснива на пластичком динамизму хоризонтално рашчлањених маса. Иако неједнаког експресивног потенцијала, оба подухвата су подстакла млађе српске градитеље да пројектују знатно слободније, махом евоцирајући древне српско-византијске архитектонске склопове. ${ }^{56}$

Остали учесници на конкурсу су поступили неуједначено по питању предвиђених пропозиција, примењујући прижељкиване срйске мотиве (трећепласи- рани Владимир Поповић и у првом кругу одбачени Момир Коруновић), док су другопласирани Несторовић и Ђорђевић инсистирали на слободнијој варијанти анационалног академизма. На послетку, чешки аутор је приложио пројекат у маниру средњоевропског романтизма, морфолошки још удаљенијег од локалног поднебља и културе.

\section{Закључак}

У српској историографији штуро квалификован као пример северноевройске сеиесије, а потом и рускої акаgемизма, ${ }^{57}$ рад Кричинског и Васиљева је тек недавно потпуније анализиран. ${ }^{58}$ Његове неуједначене класификације су превасходно проистицале из неусклађености српске с руском историографијом, у којој је визуелни идентитет балтичке модерне препознат са закашњењем.

Понешто суморан, интровертан и загонетан, пројекат Кричинског и Васиљева је знатно прикладнији северњачкој атмосфери балтичких градова него културном идентитету и клими Београда. Но упркос доминантно импортованом концепту, његова астатична силуета, употпуњена оријенталистичким детаљима, ${ }^{59}$ квалитативно би обогатила престонички амбијент у време јачања руско-српских уметничких веза након смене династија у Србији (1903). ${ }^{60}$ Индикативно је да је продубљивање сарадње Удружења српских инжењера и архитеката и Удружења руских инжењера и архитеката управо наступило у августу 1908. године, ${ }^{61}$ током појачане културне активности београдског Руско-српског клуба (основан 1901) и све чешћих посета руских туриста. ${ }^{62}$ Непосредни одјеци надахнутог пројекта руских аутора за Управу монопола уочљиви су на грађевинама које је Васиљев са Бубиром и Ржепишевским (Александр Ржепишевский) у наредним годинама извео у Талину, Тбилисију и Харкову, силуетно понешто усиљенијих. ${ }^{63}$

Делимичан отклон од општих канона балтичког регионализма, ${ }^{64}$ на Управи монопола оличен у оријенталистичким куполама изнад централних ризалита, представља уступак традицији и идеолошкој оријентацији српске постотоманске средине, у којој је евоцирање нароgних мотива имало снажну мобилизаторску димензију. Интегративна идеолошка компонента којој је Министарство тежило подједнако је потцртана на духовном и емотивном, колико и конвенционално препознатљивом симболичком плану. Духовна мобилност и патриотски активизам који палата реторички подстиче понуђени су као путоказни принципи националне економске еманципације, док йврђавска затвореност са стражарницама у павиљонској супструк- 
цији показује опредељење државе да се супротстави традиционалним завојевачима и започне ослобођење балканских сународника. Таква иконографија је идеолошки кореспондирала с политичким идејама и процесима који ће током наредне деценије, уз високу цену, довести до остварења жељених циљева. ${ }^{65}$

Одјеци овог нереализованог пројекта уочљиви су и на појединим Васиљевљевим делима које је извео у двогодишњој емиграцији у Београду (1921-1923), пре свега у затвореним формама разуђеног Војногеографског института и лучним лођама интерполиране па- лате Саве Миленковића (сличним оним са везивних поља Управе монопола). Ипак, оба потоња остварења по експресивном капацитету знатно заостају за неизведеном стожерном палатом престоничког управног центра, која због вишеструких квалитета не би смела да се занемари у културној историографији Београда.

\author{
Проф. др Александар Ђ. Кадијевић, \\ историчар уметности \\ Филозофски факултет, Београд \\ aleksandarkadije@sbb.rs
}

\section{НАПОМЕНЕ:}

1] Brumfield 1991; Grosa 1999; Howard and Hallas Murulla 2003; Кириллов 2011; Левошко 2014; Кириков 2016; Лисовский 2016.

2] Неговане су током честих сусрета, помним праћењем међусобног рада, заједничким реализацијама, конкурсима и плодном сарадњом националних стручних удружења. Видети: Howard and Hallas Murulla 2003: 6.

3] Howard 1996: 137-207; Meister 1999.

4] Hatje 1970: 232-233; Hausen et al. 1990; Howard 1996: 170-173; Howard and Hallas Murulla 2003: 34-39.

5] Уз Барселону, Будимпешту, Варшаву, Букурешт, Софију, Атину, Београд и друге регионалне центре у којима је владала изразитија подвојеност на инспирисан националном традицијом и интернационални ток ар нувоа.

6] Howard 2006: 90-91.

7] Несторовић 1937: 74; Шкаламера 1967: 320-321; Јовановић 1992: 276-278; Кадијевић 1996: 28-31; Bogunović 2005: 521; Јанакова Грујић 2006: 75-78, 82-87; Banović 2010: 156; Јахонтов и Просен 2013: 117, 119.

8] Саблин 1998; Howard and Hallas Murulla 2003: 104, 124; Кириков 2012: 180-188.

9] Јахонтов и Просен 2013: 116-117.

10] Степан Самойлович Кричинский: Некролог, № 1 (Ленингра́д 1924): 43-46.

11] Лисовский и Исаченко 1999; Лисовский и Гашо 2011.

12] Лисовский и Гашо 2011: 255-257.

13] Хрисанф А. Виноградов, дипломирао као грађевински инжењер на Високој Николајевској војној инжењерској академији у Санкт Петербургу. Члан Секције Београд УЈИА од 1928. године. Нострификовао дипломску исправу на Техничком факултету Универзитета у Београду 14. 3. 1931. год. (Марковић 1939: XVIII)

14] Сӣроїа, суха и чистиа йехника раяова ї. Николе Васиљева йри-

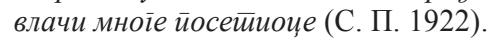

15] Миленковић 1997: 49.

16] Леко 1926: 194-195.

17] Кадијевић 1994: 294.

18] У жирију су били угледни професори загребачке Техничке високе школе арх. Едо Шен и инж. Милан Чалоговић, као и арх. Лав Калда (Bagarić 2011: 211, 257).
19] На конкурс расписан почетком августа 1922. године, на којем прва награда није додељена (у жирију је од уметника једино био вајар Симеон Роксандић), пристигла су три цртежа и осам гипсаних скица. Под шифром Србија, Васиљев је приложио маштовити романтични пројекат неодорског храма (Лисовский и Гашо 2011: 260-261). Оцењено је да се одликује монуменйалном величансиивеношћу, али да је скулпторска композиција превише подређена архитектури (Политиика, 5. 10. 1922: 4). Скромни привремени пирамидални споменик извео је арх. Милан Минић, да би 1937. био изграђен репрезентативни државни монумент према пројекту Ивана Мештровића.

20] Иницирана још 1920. године у сарадњи са проф. Душаном Томићем, прва награда је додељена тек јануара 1924. године. Уз чланове УЈИА, једино су руски архитекти емигранти имали право да се кандидују с поднетим нацртима и фотографијама. У жирију је било заступника конзервативних, али и напредних схватања: Ђура Бајаловић, Милан Милутиновић, Милица Крстић, Милан Минић и Милан Злоковић (Стручне вести. Стечај за најлепшу фасаду извршену у Београду након рата, Технички листи 12, Загреб: 15. 6. 1923: 88-89). У штампи је напоменуто да је Оиењивачки суg нашао gа наїраgу ї. Томића заслужује

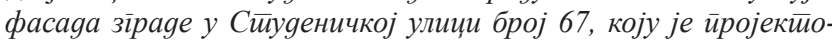

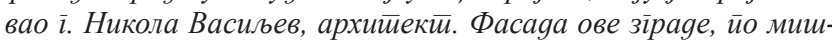
љењу оценивачкоі суяа, ояликује се јасном еиииком самосйалне комйозиције, хармоничним расйореgом маса и йовриина у лейим ояносима, и ойменом и дискрейном орнамениииком (Политиика: 25. 1. 1924: 4). О архитектури палате видети и: Јахонтов и Просен 2013: 119-120; Кадијевић 2015a: 251.

21] Игњатовић 2004: 119-124; Кадијевић 2015а: 248-249.

22] Јахонтов и Просен, 2013: 121-122.

23] Истио: $123-124$.

24] У низу фасада грађевина које сматра правилно архитектонски решеним у Београду, Ђура Бајаловић је истакао и Геоїрафски

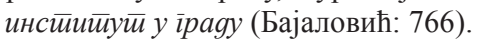

25] Пројектована је у заједничком бироу Васиљева и Хрисанфа Виноградова: Кадијевић 1994: 294; Лисовский и Гашо 2011: 262-263; Јахонтов и Просен 2013: 120-121; Латинчић 2015: 149; Кадијевић 2015б: 520-521.

26] Палата је маја 2014. претворена у хотел „Jump Inn“.

27] Историјски архив Београда, фонд ОГБ, ТД, ф 3-21-24.

28] Борисављевић 1928. 
29] Стојановић 1928.

3o] H. de Haan and I. Haagsma et al.: 115-125.

31] Prosen 2016.

32] Пројекат је евидентиран у приватној заоставштини арх. Момира Коруновића 1991. год. Будући да се у њој чува и нацрт архитеката Бранка Поповића и Бранка Максимовића за исти храм, највероватније се радило о интерном позивном конкурсу који је организовао приватни наручилац, на којем је победио Васиљев. Део документације се налази и у фонду Министарства грађевина Архива Југославије.

33] Здравковић 1940; Јахонтов и Просен 2013: 128.

34] Лисовский и Гашо 2011: 311-313.

35] Roter Blagojević 1997.

36] Стојановић 2008: 106.

37] Кадијевић 2005: 307-308.

38] Маслаћ 1909б: 105.

39] Кадијевић 1997: 228-229; Ацовић, 2017: 227-232.

40] Маслаћ 1909a: 97-98.

41] Истии 1909в: 113.

42] Истии 1909 г: 123.

43] У почетку је владало расположење да не учествују странци, али се накнадно управа ипак одлучила за отвореност ка другим словенским пројектима. Такво пансловенско опредељење се после Мајског преврата (1903) и доласком на власт династије Карађорђевић рефлектовало на прилике у српској архитектури, у којој је утицај руских стручних кругова постепено растао.

44] Маслаћ 1909а; 1909б; 1909в; 1909г; Јовановић 1992; Кадијевић 1996.

45] Маслаћ 1909г: 122.

46] Истии 1909б: 106.

47] Истии 1909в: 113.

48] Истио: 14.

49] Маслаћ 1909б: 107.

50] Исиии 1909в:114

51] Истии 1909а: 97.

52] Јанакова Грујић 2006.

53] Маслаћ 1909а; 1909б; 1909в; 1909г.

54] Истии 1909в: 114.

55] Maskareli 2006; Михајлов 2009.

56] Јахонтов и Просен 2013:119; Кадијевић 2016.

57] Шкаламера 1967: 320; Кадијевић 1996: 31.

58] Јахонтов и Просен су први детаљније анализирали замишљено здање: Пројекай Васиљева и Кричинской йорразумевао је масивну кубичну форму блока на четиири ейаже, која је, суgећи йо

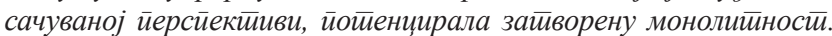

Шире лучне иеррфораичије йослеgњеї сирайа неgовољно ойварају

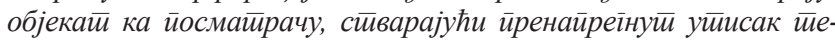

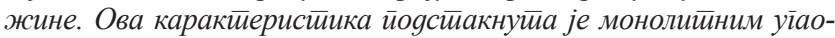

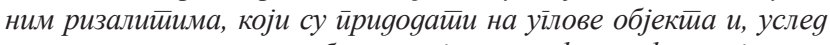
gелимичне русиикалне обраяе, gају скоро форииификацијски изілеg. Два мањ а ниска анекса фланкирају среgишьи улазни риза-

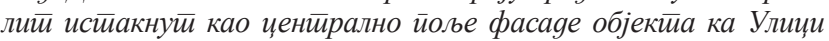
кнеза Милоша, који Васиљев у свом ирројекӣу доgайно найлашава куйолом на масивној кубичној основи и декорайивном луне-

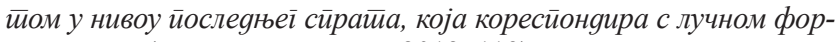
мом улаза. (Јахонтов и Просен 2013: 119)

59] Bozdogan 1986: 46-58. Европски архитектонски оријентализам је одабирао и неретко еклектички спајао традиционалне далекоисточне, средњоазијске, блискоисточне, маварске, па и византијске мотиве. Нагињали су му и свестрани руски архитекти, попут чувеног академика Николаја Петровича Краснова, посебно током кримског периода делатности (1887-1917). Видети: Ацовић 2017: 62-68, 76-85, 94-121.

6о] Непосредне руско-српске везе у архитектури ојачале су на прелазу векова, упоредо с јачањем руског политичког и војног утицаја на Балкану. Аустрофилска политика династије Обреновић усмеравала је српску архитектуру ка средњоевропским узорима, допуштајући обнову срӣско̄ стиила с неовизантијском и понегде руском градитељском компонентом. Најизразитији пример српско-руских веза у архитектури у другој половини прошлог века представља Црква Успења Богородице у Крагујевцу (1869-1884), Андреје Андрејевића, ученика предводника руског романтизма Константина А. Тона. Сменом династија у Сpбији 1903. године, архитектонска политика се преусмерава ка продубљивању српско-руских веза. У Горњем Адровцу се 1903. године подиже спомен-црква добровољца и страдалника из српско-турских ратова пуковника Рајевског, са обележјима традиционалне руске архитектуре. Утицај руских културних установа у Србији појачан је 1904. године, када је Академија уметности из Санкт Петербурга процењивала конкурсне радове за Храм Св. Саве на Врачару. Одбацила је два рада јер нису у визанииијском сииилу, а три је, уз извесне примедбе, препоручила за реализацију.

Ауторитет руских стручних кругова потврђен је 1907. године када је дирекција осигуравајућег друштва „Росија“ (касније хотел „Москва“) за извођење свог репрезентативног здања у Београду предложила другонаграђени конкурсни рад Јована Илкића, уз извесне измене основе и фасаде. Разрадом Илкићевог пројекта коју су извели непознати санктпетербуршки архитекти, утицај руских установа на српско градитељство је видно ојачао, кулминиравши на конкурсу за зграду Управе монопола (1908). О српско-руским везама на пољу осталих ликовних уметности видети: Јовановић 1983.

61] Руски уметиници о срӣским стиаринама 1909: 123.

62] Стојановић 2008: 261, 323.

63] Лисовски и Гашо: 206-232.

64] Изостале су косе и стрме вишеводне кровне равни, оштри и залучени троугаони забати.

65] Стојановић 2003; Попов 2007; Стојановић 2008; Stojanović 2013; Ковић 2015. 


\section{ЛИТЕРАТУРА:}

Ацовић, Д. (2017), Николај Краснов. Албум сећања, Београд: Хералдички клуб.

Bagarić, M. (2011), Arhitekt Ignjat Fischer, Zagreb: Meandarmedia i Muzej za umjetnost i obrt.

Бајаловић, Ђ. (1932), Ка старом српском стилу, Беоїраgске ойшииинске новине 12, (Београд): 766-769.

Banović, A. (2010), Beograd 1930-2009, Beograd: Alboinženjering.

Bozdogan, S. (1986), Orientalism and Architectural Culture, Social Scientist Vol. 14, No. 7: 46-58.

Bogunović, S. G. (2005), Arhitektonska enciklopedija Beograda XIX $i$ XX veka, Beograd: Beogradska knjiga.

Борисављевић, М. (1928), Архитект или инжењер?, Правgа (Београд), 29. 5. 1928: 9.

Brumfield, W.C. (1991), The Origins of Modernism in Russian Architecture, Berkeley: University of California Press.

Grosa, S., (ed.) (1999), Art Nouveau. Time and Space. The Baltic Sea Countries at the Turn of 20th Century, Riga: Jurava.

Здравковић, И. (1940), Исход конкурса за Београдску оперу, Уметинички йреїлеg ІІІ (Београд): 140-148.

Игњатовић, А., (2004), Две београдске куће архитекте Драгише Брашована, Наслеђе V (Београд): 119-134.

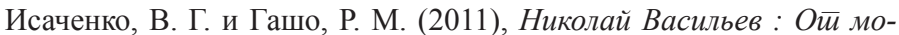
gерна к модернизму, Санкт Петербург: Коло.

Јанакова Грујић, М. (2006), Архийекӣа Драйуӣин Маслаћ (18751937), Београд: Центар ВАМ.

Јахонтов, А. и Просен, М. (2013), Стваралаштво архитекте Николаја Васиљевича Васиљева и његов београдски опус (мај 1921 фебруар 1923), Наслеђе XIV (Београд): 115-133.

Јовановић, М. (1983), Српска ликовна уметност и Русија крајем XIX и почетком XX века, Саоййень Р Р33СК XV (Београд): 119-127.

Јовановић, М. (1992), Архитект Владимир Поповић (1876-1947), Саойшиеюьа РЗ33СК XXIV (Београд): 275-286.

Кадијевић, А. (1994), Изложбе руских архитеката у Београду између два светска рата, у: Руска емиіррација у срйској кулииури ХХ века, књ. 1, ур. М. Сибиновић, Београд: Филолошки факултет: 293-301.

Кадијевић, А. (1996), Момир Коруновић, Београд: Републички завод за заштиту споменика културе : Музеј науке и технике : Музеј архитектуре.

Кадијевић, А. (1997), Рад Николаја Краснова у Министарству грађевина Краљевине СХС/Југославије у Београду од 1922. до 1939. године, Гоgишњак їраgа Беоїраga XLIV, (Београд): 221-255.

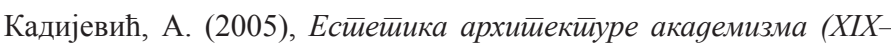
XX век), Београд: Грађевинска књига.

Kadijević, A. (2015a), Interpolations - necessity and inspiration of newer Belgrade architecture, Matica srpska Journal for fine arts 43 (Novi Sad): 243-258.
Kadijević, A. (2015б), Savsko priobalje u Beogradu (1918-1941) pogled na arhitektonsko-urbanistički razvoj, u: Rijeka Sava u povijesti (zbornik radova), ur. B. Ostajmer, Slavonski Brod: Hrvatski institut za povijest, podružnica Slavonski Brod: 507-526.

Кадијевић, А.(2016), Визанӣијско ірраяииеељстиво као инсӣираиија срйских неимара новијеі gоба/Byzantine architecture as inspiration for Serbian New Age architects, Београд/ Belgrade: SANU, Serbian Comitee for Byzantology.

Кириков, Б. М. (2012), Архийекӣира иеетербурі̄скоі̄o моgерна. Особняки и gоходные gома, Санкт-Петербург: Коло.

Кириков, Б. М. (2016), Архииекейура иееиербурской модерна. Общестивенные зяания, Санкт-Петербург: Коло.

Кириллов, В. В. (2011), Архийекӣура 'севернойо модерна', Москва: Либроком.

Ковић, М. (прир.) (2015), Срби 1903-1914. Исйорија ияеја, Београд: Clio.

Латинчић, О. (2015), Прилози биографијама руских архитеката градитеља Београда, Наслеђе XVI (Београд): 147-160.

Леко, Д. М. (1926), Нова зграда Министарства пољопривреде и вода и Министарства шума и рудника, Технички лисй 13-14 (Загреб): 193-203.

Лисовский, В. Г. (2016), Северный модерн. Национально-романиичческое найравление в архииекииуре ситран Балиийскоїо моря на рубеже XIX и XX веков, Санкт Петербург: Коло.

Левошко, С. С. (ур.) (2014), Архииекейура эйохи моgерна в сииранах Балииийскойо реїиона, Санкт-Петербург: Коло.

Лисовский, В. Г. и Исаченко, В. Г. (1999), Николай Васильев, Алексей Бубырь, Санкт-Петербург: Белое и Чёрное.

Марковић, В. С. (прир.), Именик gийломираних инжињера и архииекайа на Техничком факулиеейу Универзийейа у Беоїраяу 1919 1938, Београд: Технички факултет.

Maskareli, D. (2006), Hotel 'Moskva' u Beogradu, DaNS 55 (Novi Sad): 70-71.

Маслаћ, Д. (1909а), Скице за зграду Монополске управе, Срйски иехнички листи 13 (Београд): 29. 3. 1909: 97-99.

Маслаћ, Д. (1909б), Скице за зграду Монополске управе, Срйски иехнички листи 14 (Београд), 5. 4. 1909: 105-107.

Маслаћ, Д. (1909в), Скице за зграду Монополске управе, Срйски иехнички листи 15 (Београд), 12. 4. 1909: 113-115.

Маслаћ, Д. (1909г), Скице за зграду Монополске управе, Срйски иехнички листи 16 (Београд), 19. 4. 1909: 121-123.

Meister, M. (ed.) (1999), H. H. Richardson: The Architect, His Peers, and Their Era, Cambridge MA.: MIT Press.

Миленковић, Т. (1997), Руски инжењери у Јуіославији 1919-1941, Београд: Савез инжењера и техничара.

Михајлов, С. (2009), Хойел 'Москва', Београд: Завод за заштиту споменика културе града Београда.

Најлепша фасада у Београду (1924), Полийика (Београд): 25. 1. 1924: 4. 
Несторовић, Н. (1937), Грађевине и архииеккӣи у Беоіраgу ӣрошлої сйољећа, Београд: УЈИА, Клуб архитеката.

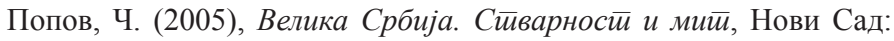
Издавачка књижара Зорана Стојановића.

Prosen, M. (2016), The Participation of Russian Architects and Sculptors in Making the Art Deco Architecture in Serbia, in: Actual Problems of Theory and History of Art, eds. E. Stanyukovich-Denisova and S. Maltseva, Sankt Peterburg: State University: 624-634, 904.

Roter Blagojević, M. (1997), Duh nove epohe. Nastanak i izgradnja finansijskih ustanova novčanih zavoda u Beogradu tokom XIX i početkom XX veka (1830-1914), G magazin 4 (Beograd): 51-54.

Руски уметници о српским старинама (1909), Срйски иеехнички листи 16 (Београд): 19. 4. 1909: 123.

Саблин, И. Д. (1998), Степан Кричинский, у: Зоgчие Санкй-Пеиербурїа. XIX-начало XX века, ур. В. Г. Исаченко; ред. Ю. Артемьева, С. Прохватилова, Санкт Петербург: Лениздат: 826-841.

Споменик Незнани јунак (1922), Полииика (Београд): 5. 10. $1922: 4$.

Стојановић, С. (1928), Руска емиграција и уметност код нас, Мuсао 1-2 (Београд): 76.

Стојановић, Д. (2003), Србија и gемокрайија 1903-1914, Београд: Удружење за друштвену историју.
Стојановић, Д. (2008), Калярма и асфалй. Урбанизачија и евройеизаuија Беоїраga 1890-1914, Београд: Удружење за друштвену историју.

Stojanović, D. (2013), Iza zavese. Ogledi iz društvene istorije Srbije 1890-1914, Beograd: Udruženje za društvenu istoriju.

С. П. (1922), Руска изложба у Београду, Мисао (Београд): 4. 9. 1922: 717.

Haan, H. and Haagsma, I. et al., (1988) Architects in Competition. International Architectural Competetions of the last 200 years, London: Thames and Hadson.

Hatje, G. (ur.) (1970), Enciklopedija moderne arhitekture, Beograd: Građevinska knjiga.

Hausen, M. et al.(1990), Eliel Saarinen. Projects 1896-1923, Cambridge Mass.: MIT Press.

Howard, J. (1996), Art Nouveau. International and National styles in Europe, Manchester: University Press.

Howard, J. and Hallas Murulla, K. (eds.) (2003), Architecture 1900. Stockholm, Helsinki, Tallin, Riga St. Petersburg, Talin: Museum of Estonian Architecture.

Howard, J. (2006), East European Art 1650-1950, Oxford: University Press.

Шкаламера, Ж. (1967), Сецесија у архитектури Београда 1900 1914, Зборник Майице срииске за ликовне уметиносиии 3, (Нови Сад): $313-340$.

\section{Summary: ALEKSANDAR KADIJEVIĆ}

\section{BALTIC MODERNISM IN BELGRADE: DESIGN OF THE BUILDING OF THE MONOPOLY ADMINISTRATION AND THE MINISTRY OF FINANCE IN BELGRADE (1908) BY KRICHINSKY AND VASILYEV}

In contemporary architectural historiography, the term "Baltic Modernism" denotes a specific regional branch of the international Art Nouveau movement. With its centres in Saint Petersburg and Helsinki, Baltic Modernism spread to Stockholm, Riga, Tallinn and other Baltic cities in the period between 1900 and 1914. Although it was a blend of Nordic and Slavic artistic elements, due to personal relationships between Baltic architects it featured stylistic consistency. This also accounts for the renowned Russian architects, Stepan Krichinsky (Степан Самойлович Кричинский) and Nikolay Vasilyev (Николай Васильевич Васильев), whose awarded competition design of the Building of the Monopoly Administration and the Ministry of Finance in Belgrade (1908) has been partially addressed in Serbian historiography. However, it has never been fully examined in architectural context from which it was derived.

The unorthodox building by Krichinsky and Vasilyev, of a restless "Baltic" silhouette and presenting medieval reminiscences and Orientalist details, represents the peak of the authors' inspiration; it was also illustrative of the position of the Ministry that national unity could only be achieved with the help of strong financial institutions. The unique and unusual building for the then Belgrade milieu, predominantly inspired by Central European academic models, this four-floor "modern" palace - with its zones organically interconnected instead of being hierarchically delineated - would outclass in compactness the building by the architect Krasnov, created in a formal neo-mannerist fashion with an overstressed angular segment. 


\section{Illustrations}

Fig. 1 House of the Illustrator Sherbov in Saint Petersburg (S. Krichinsky, 1910-1911, Музей-усадьба П. Е. Щербова)

Fig. 2 New Passage at Liteiny Prospekt in Saint Petersburg (N. Vasilyev, 1912-1913, http://www.citywalls.ru)

Fig. 3 German Theatre in Tallinn (N. Vasilyev and A. Bubyr, 19081910, http://www.wikiwand.com/ru/Васильев,_Николай_Васильевич)

Fig. 4 Palace of Sava Milenković at 65 Svetozara Markovića Street in Belgrade (N. Vasilyev, 1921-1922, photograph: A. Kadijević, 2017)

Fig. 5 Military Geographical Institute in the west bastion of Belgrade Fortress (N. Vasilyev, 1924-1926, postcard)

Fig. 6 Palace of Rista Paranos at 67 Karađorđeva Street in Belgrade (N. Vasilyev and H. Vinogradov, 1922-1923, photograph: A. Kadijević, 2012)

Fig. 7 Awarded competition design of the Building of the Monopoly Administration and the Ministry of Finance of the Kingdom of Serbia (S. Krichinsky and N. Vasilyev, 1908, ground-floor plan, Srpski Tehnički List 13, 29 March 1909, 98)

Fig. 8 Awarded competition design of the Building of the Monopoly Administration and the Ministry of Finance of the Kingdom of Serbia (S. Krichinsky and N. Vasilyev, 1908, perspective view, Srpski Tehnički List 13, 29 March 1909, 97) 